CT\&F - Ciencia, Tecnología y Futuro - Vol. 4 Num. 4 Dec. 2011

ctył@ecopetrol.com.co

\title{
FACTORS DETERMINING THE PHYTOPLANKTON VARIABILITY IN THE SWAMPS OF THE MOMPOSINA DEPRESSION (COLOMBIA)
}

\author{
Yasmín Plata-Díaz ${ }^{1}$ and Astrid-Lorely Pimienta-Rueda ${ }^{2 *}$ \\ ${ }^{1}$ TIP. -PETROLABIN, Bucaramanga, Santander, Colombia \\ ${ }^{2}$ Ecopetrol S.A. - Instituto Colombiano del Petróleo (ICP), A.A. 4185 Bucaramanga, Santander, Colombia
}

e-mail: astrid.pimienta@ecopetrol.com.co

(Received March 28, 2011 ; Accepted Oct. 03, 2011)

\begin{abstract}
$\mathrm{D}$ escription of the main environmental factors that structure phytoplankton dynamic in 27 swamps of the Momposina depression located in the area of influence of the Cicuco-Boquete oil field. According to the results, the parameters that determined the variations in the physics and chemistry of the water are related to system hydrology, followed by the variables associated with the industrial operation, particularly in relation to chloride content and natural mineralization, which is due to conductivity and alkalinity.

The euglenoids were the most common throughout the study, particularly during low water periods; cyanobacteria density increased in high waters and pennate diatoms in rising water. The lowest average diversity and richness were reported in the systems with the highest domestic and industrial impact as well as in the swamp referenced herein.

Variations in phytoplankton composition were not related to the hydrological periods studied. $\mathrm{pH}, \mathrm{NO}_{3}$, conductivity and the organic load $\left(B O D_{5}\right)$, as well as variables indirectly related to the industrial operation (chlorides and COD) were determining variables. Total hydrocarbons were not a significant variable in the community structure.
\end{abstract}

Keywords: Phytoplankton, Swamps, Momposina depression, Flood pulse, Domestic pollution, Oil activity.

Citation: Plata-Díaz, Y. \& Pimienta, A. L. (2011) Factors determining the Phytoplankton variability in the swamps of the Momposina depression (Colombia). CT\&F - Ciencia, Tecnología y Futuro, 4 (4), 105-122.

*To whom correspondence should be addressed 


\section{RESUMEN}

e describen los principales factores ambientales que estructuran la dinámica del fitoplancton en 27 ciénagas de la depresión Momposina, ubicadas en el área de influencia del campo petrolero Cicuco-Boquete. De acuerdo con los resultados, los parámetros que determinaron las variaciones en la física y química del agua están relacionados con la hidrología de los sistemas, seguida de las variables asociadas con la operación industrial, específicamente en relación al contenido de cloruros así como la mineralización natural, que puede ser explicada por la conductividad y la alcalinidad.

Los euglenoideos fueron los de mayor ocurrencia a lo largo del estudio, particularmente en los períodos de aguas bajas; las cianobacterias aumentaron en densidad en aguas altas y las diatomeas pennadas proliferaron en los períodos de aguas en ascenso. Los más bajos promedios de diversidad y riqueza de especies, fueron registrados tanto en los sistemas con mayor impacto doméstico e industrial así como en la ciénaga de referencia.

Las variaciones en la composición del fitoplancton no estuvieron relacionadas con los periodos hidrológicos estudiados. $\mathrm{El} \mathrm{pH}$, los $\mathrm{NO}_{3}$, la conductividad y carga orgánica $\left(\mathrm{DBO}_{5}\right)$, así como las variables indirectamente relacionadas con la operación industrial (cloruros y DQO) fueron las variables determinantes. Los hidrocarburos totales no constituyeron una variable significativa en la estructura de la comunidad.

Palabras Claves: Fitoplancton, Ciénagas, Depresión Momposina, Pulso de inundación, Contaminación doméstica, Actividad petrolera.

\section{RESUMO}

F

oram descritos os principais fatores ambientais que estruturam a dinâmica do fitoplancto em 27 pântanos da depressão Momposina, localizados na área de influência do campo petroleiro CicucoBoquete. De acordo com os resultados, os parâmetros que determinaram as variações nos aspectos físicos e químicos da água estão relacionados com a hidrologia dos sistemas, seguidos pelas variáveis associadas com a operação industrial, especificamente em relação ao conteúdo de cloretos, assim como a mineralização natural, que pode ser explicada pela condutividade e pela alcalinidade.

Os euglenoides foram os de maior incidência ao longo do estudo, particularmente nos períodos de baixa no nível das águas; as cianobactérias aumentaram em densidade no período de cheia e as diatomáceas penadas proliferaram nos períodos de crescente. As médias mais baixas de diversidade e de riqueza de espécies foram registradas tanto nos sistemas com maior impacto doméstico e industrial como no pântano de referência.

As variações na composição do fitoplancto não estiveram relacionadas com os períodos hidrológicos estudados. $\mathrm{O} \mathrm{pH}, \circ \mathrm{NO}_{3}$, a condutividade e a carga orgânica $\left(\mathrm{DBO}_{5}\right)$, assim como as variáveis indiretamente relacionadas com a operação industrial (cloretos e $D Q O$ ) foram as variáveis determinantes. Os hidrocarbonetos totais não constituem uma variável significativa na estrutura da comunidade.

Palavras-chaves: Fitoplancto, Pântano, Depressão Momposina, Pulso de inundação, Contaminação doméstica, Atividade petroleira. 


\section{INTRODUCTION}

Swamps are bodies of water located in shallow depressions connected to the river by narrow, meandriform channels. They can be formed by the flooding action of the river on adjacent lowlands and by the continuous erosive action of the river, originating branches that become swamps and remain connected to the river by one or more streams (Roldán \& Ramírez, 2008).

In Colombia, these systems are mainly located in the basins of the Magdalena, the Lower San Jorge and the Lower Cauca Rivers (Montoya \& Aguirre, 2009a) and they are the main elements of flood plains. Swamps are located in low-lying zones (altitude between 0 and 1000 $\mathrm{m})$ and they are characterized by warm temperatures (between $24^{\circ} \mathrm{C}$ and $32^{\circ} \mathrm{C}$ ) and their shallow depth, usually less than $5 \mathrm{~m}$ (Ramírez \& Viña, 1998). From the ecological standpoint, in alluvial plains systems, the flood pulse constitutes the main force that controls the structure and dynamics of organisms (Junk, Bayley \& Sparks, 1989). In turn, this process favors fishing, the development of fauna and forests, and the processes of sedimentation and purification in wetland systems (Junk, 1997).

The area of influence of the Cicuco-Boquete oil field is located in the southern region of the Department of Bolivar (Colombia) between the towns of Cicuco, Talaigua Nuevo and Mompos (ICP, 2001a). This zone is a part of the lower Magdalena River basin and it is surrounded by the Loba Branch on the west and the Mompox branch on the east. Since it is a lower zone in relation to its surroundings, it tends to flood over during the Magdalena River's high water periods.

This paper describes the dynamics of the phytoplankton in 27 swamps of the Momposina depression located in the area of influence of the Cicuco Field over a period of 4 years of biannual monitoring. The community structure (composition and diversity) was analyzed in regard to the abiotic variables, in order to assess the main factors related to the occurrence of the most common taxonomic orders of the phytoplankton in the different swamps.

Considering the high level of sensitivity of these ecosystems, and the historic information collected over several years of monitoring, a study of the determining environmental factors in phytoplankton composition and diversity plays an important role in understanding the dynamic of these systems. Therefore, this paper was focused on establishing whether the environmental variables or domestic $\left(\mathrm{BOD}_{5}\right.$, fecal coliforms) and industrial ( $C O D$, chlorides, total hydrocarbons) pollution affect the phytoplankton structure of the swamps in the Momposina Depression in the area of influence of the Cicuco Field.

\section{METHODOLOGY}

\section{Area of study}

The area of study is in the northeastern sector of the Momposina depression, which comprises the set of wetlands created by the influence of the San Jorge, Cauca and Magdalena Rivers. It is located in the Caribbean plains region of Colombia and it is surrounded by the towns of Hatillo de Loba, Margarita, San Fernando, Mompox, Talaigua Nuevo and Cicuco, between the geographic coordinates $09^{\circ} 20^{\prime} 03,50^{\prime \prime} \mathrm{N} 74^{\circ} 39^{\prime} 47,50^{\prime}$ 'W northwestern limit, $09^{\circ} 18^{\prime} 00,69^{\prime \prime} \mathrm{N} 74^{\circ} 33^{\prime} 17,20^{\prime \prime} \mathrm{W}$ northeastern limit, $09^{\circ} 11^{\prime} 16,98^{\prime \prime} \mathrm{N} 74^{\circ} 32^{\prime} 49,90^{\prime \prime} \mathrm{W}$ southeastern limit and $09^{\circ} 12^{\prime} 03,7^{\prime \prime} \mathrm{N} 74^{\circ} 41^{\prime} 25,96^{\prime \prime} \mathrm{W}$ southwestern limit (Department of Bolívar).

The zone's hydrographic network drains and forms part of the Magdalena River, which feeds a network of interconnected channels and branches that make up numerous permanent swamps. In the area of influence of the Cicuco-Boquete Fields, there are thought to be approximately 500 swamps (ICP, 2000).

The 27 bodies of water that were studied are distributed in an area of approximately $852 \mathrm{~km}^{2}$ between the Loba and Mompox Branches of the Magdalena River (Figure 1). Most of the zone is surrounded not only by the oil infrastructure, but also by settlements amounting to $25 \mathrm{~km}^{2}$ of rural area and $78 \mathrm{~km}^{2}$ of urban area, just in the town of Cicuco. The livelihood of the population in the area of influence consists of cattle-raising, fishing and subsistence farming. 


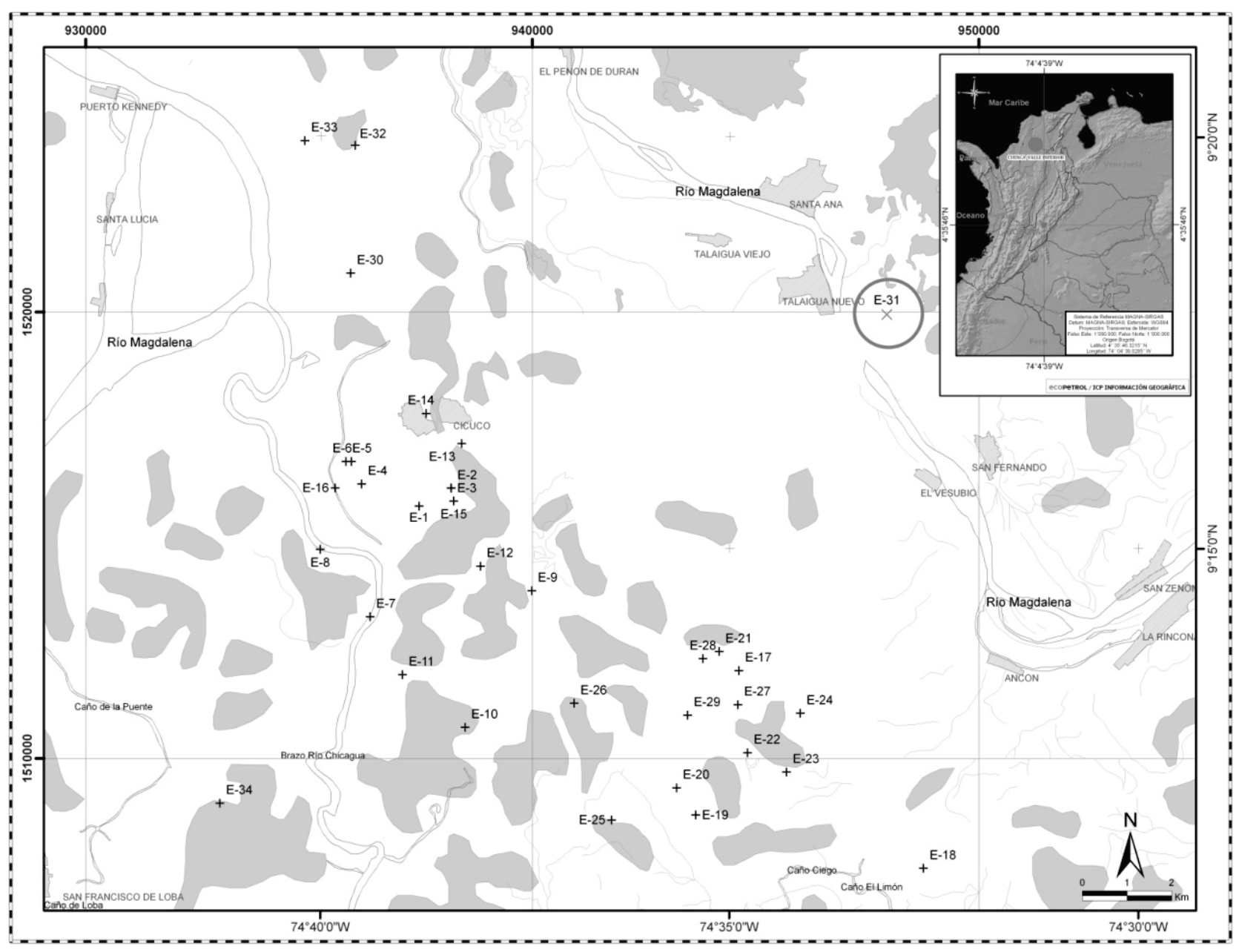

Figure 1. Geographic location of the zone of study of the Momposina depression in the northern region of Colombia. The figure illustrates the bodies of water that were monitored (including rivers beyond the scope of this paper). The numbers are the stations mentioned herein. The location of the swamp referenced herein has been circled in the illustration.

Twenty six of the systems that were studied are distributed between the northeastern and the southwestern of the oil field and just one (E31) is far from its area of influence and, therefore, considered the reference site. Macrophyte coverage is a distinctive characteristic of the swamps that were studied. The most commonly reported species are Eicchornia crassipes and Paspaplum repens.

The field's general infrastructure consists of two stations (Cicuco Station and Boquete Station), which receive the crude from the different wells on the alluvial plain of the systems, as well as a pumping station, a gas plant and a gas compression plant, which is in the industrial area of the town of Cicuco. During the high water period, several wells become covered and when the levels drop, the water breaks the terraces in the zone (ICP, 2000).
The main impacts on the swamp complexes in the zone are construction of access roads to the wells through the bodies of water by Colombian Petroleum Company (COLPET) in the 1950s, as well as the construction of a national road that divided swamps and intersected channels (ICP, 2000).

\section{Sampling}

Biannual sampling campaigns began in the year 2006 in order to cover two seasons per year: high water and low water (Figure 2). However, given the environmental variability caused by "La Niña" (2007) some of the biannual campaigns were carried out during similar hydrological periods (high water and ascending waters). Stations were chosen based on the baseline characterization (ICP, 2001a) and a code was assigned to each of them for sample organization purposes. 


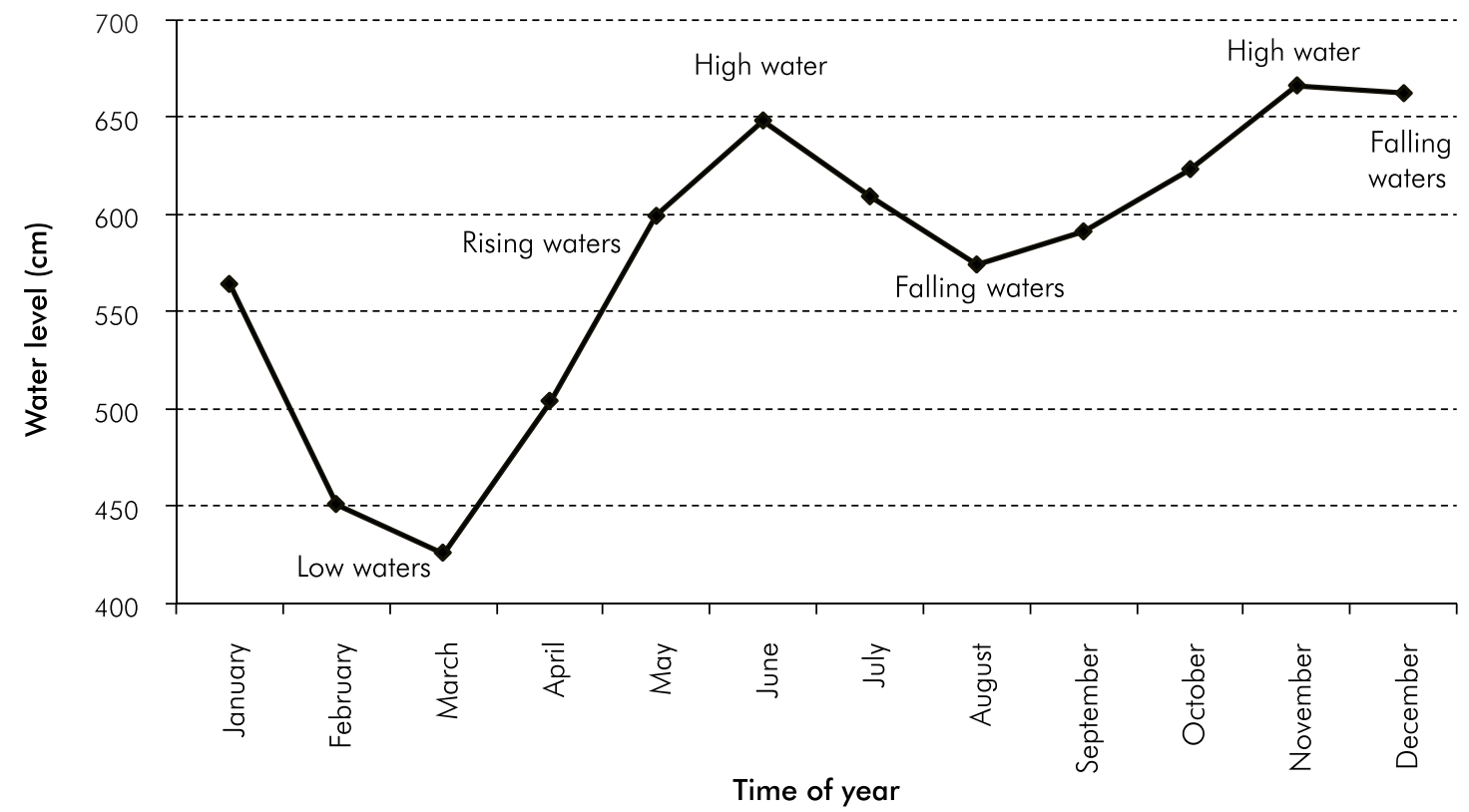

Figure 2. Mean multi-annual monthly water levels of the Chicagua River, Guaymaral Station (1991-2009) and hydrological periods. Source: IDEAM Database, 2010.

One sampling point was chosen for each swamp in the limnetic zone. However, Stations E1, E2 and E3 are part of one system (El Mechón Swamp), and E4, E5 and E6 make up La Borda Swamp. These two systems have had the most anthropic intervention. The first (E1) went through the industrial operations of the COLPET in the 1960s, while the connection between the Borda system and its main channel was altered by the construction of the Mompox-Cicuco-Bodega road, the chemicals used by neighboring farmers and gas pipe leaks (ICP, 2001b).

In all the bodies of water, the in situ variables (temperature and $\mathrm{pH})$ were taken from the subsurface $(0,1 \mathrm{~m}$ deep) in the limnetic zone of all the systems by a YSI556 multiparameter meter; transparency was measured using a Secchi disk and depth was measured by a Wildco sonar gun (126-A10); dissolved oxygen was quantified by titration with a Merck kit. The specifications established by AWWA 1060 (APHA, 2005) were followed for taking and preserving the samples of hardness, alkalinity, total hydrocarbons, nitrates, nitrites, organic nitrogen, ammonium nitrogen, total phosphorous, dissolved oxygen, chlorides, suspended solids, $B O D_{5}$ and $C O D$. The samples were analyzed in the Water and Soil, Chromatography and Spectroscopy Laboratories of the Ecopetrol S.A.- Instituto Colombiano del Petroleo (ICP).
For bacteriological analysis (fecal coliforms) and hydrobiological (phytoplankton), samples were analyzed in the biotechnology lab of said institute.

The study considered the fecal coliforms and $\mathrm{BOD}_{5}$ as indirect variables of domestic pollution, while total hydrocarbons, $C O D$ and chlorides were considered associated with the operation. In addition, they are all required to comply with Decree 1594 /84.

Phytoplankton samples were taken at each station with a Van Dorn bottle and later filtering 20 L using plankton net $(20 \mu \mathrm{m})$. The samples were immediately preserved in Transeau solution in a 1:1 ratio. The count was carried out in a Palmer-Maloney counting cell with a Nikon Eclipse E-100 microscope up to 100 individuals of the most abundant species, later recording rare species ( $18 \%$ counting error). Both the filamentous and colonial organisms were counted as an individual in all the cases. Densities were recorded as relative abundance.

Specific keys for each group were taken into account for taxonomic determination, which was based on the works of Komárek and Anagnostidis (1999, 2005), Comas (1996), Tell and Conforti (1986), Cox (1996), 
Krammer and Lange-Bertalot (1991a, b), Wehr, Sheath and Thorp (2002), among others.

\section{Statistical Analysis of the Information}

The physical-chemical patterns of the bodies of water were established by applying the Principal Components Analysis (PCA) method. If two variables displayed high correlation, one of them was omitted. Variance was fractioned by successive runs and the exclusion of variables that had a low correlation with the components, up to the maximum accumulated percentage in the first three components using Statistica V. 8,0 software (StatSoft, 2007).

Variability in the community structure was analyzed using the Shannon-Wiener diversity index, species richness (number of species), Simpson's dominance and evenness. The taxon-environment relationship was established by a Canonical Correspondence Analysis (CCA) (Jongman, Braak \& Tongeren, 1995) using Canoco V. 4,5 software (Braak \& Smilauer, 1997). This technique is appropriate when the species show unimodal distribution patterns at environmental gradients (Braak \& Prentice, 1988), unlike the Canonical Correlation Analysis, which assumes linear patterns (Palmer, 2010). However, the CCA is an efficient technique, even if the assumption of unimodal response is not fulfilled (Palmer, 1993).

\section{RESULTS}

\section{Physical-chemical variability}

The results compiled for the physical and chemical variables of the study between 2006 and 2010 are illustrated in Table 1.

The maximum values of conductivity (COND), hardness (HAR), alkalinity (ALKA) and chlorides $(C l)$ were recorded in Swamp E1, particularly in the years 2009 and 2010. In regard to nutrients, total phosphorous (TP) concentrations were very low at most of the sites $(0,01$ $\left.\mathrm{mg} \cdot \mathrm{L}^{-1}-0,49 \mathrm{mg} \cdot \mathrm{L}^{-1}\right)$ and the maximum nitrate $\left(\mathrm{NO}_{3}\right)$ values were recorded in E5 and E6 in 2007. There was a wide range of organic nitrogen $(T K N)\left(0,1 \mathrm{mg} \cdot \mathrm{L}^{-1}\right.$ $\left.18,3 \mathrm{mg} \cdot \mathrm{L}^{-1}\right)$, whose maximum value was recorded at Site E26 in 2007. The maximum values of dissolved oxygen $\left(D O=12,5 \mathrm{mg} \cdot \mathrm{L}^{-1}\right)$ and $\mathrm{pH}(9,17)$ were observed in E6 in 2006.

The water temperature of the swamps ranged from $22,3^{\circ} \mathrm{C}-35,8^{\circ} \mathrm{C}$. According to observation, conductivity, chlorides, nitrites $\left(\mathrm{NO}_{2}\right)$ and fecal coliforms (FColi), showed the highest variation, in that order (Table 1). In turn, in regard to nutrients, the low variability of total phosphorous $(T P ; C V=0,76)$ and ammonium $\left(\mathrm{NH}_{3} ; \mathrm{CV}=0,92\right)$ stood out. In relation to the variables associated with the industrial operation, chemical oxygen demand $(C O D)$ displayed a lower range of variation $(C V=0,44)$ than total hydrocarbons (THC; $C V=0,93) . \mathrm{pH}$, temperature and dissolved oxygen also showed small ranges of variation.

According to the Kruskal-Wallis test, $C O D(H=54$ $005 ; p=0,0010)$, biochemical oxygen demand $\left(D B O_{5}\right.$; $H=38,64 ; p=0,0528)$, chlorides $(H=82,87 ; p=0,00)$ and conductivity $(H=59,16 ; p=0,0002)$ showed significant spatial differences, while between sampling ("low water" and "high water"), only nutrients, conductivity, hardness and alkalinity showed important differences $(p<0,05)$, possibly as a result of the sampling periods chosen over the last few years (2008 - 2010), which were contrasting hydrological periods.

Conductivity was highly and directly related to hardness $\left(r^{2}=0,990, p<0,001\right), C O D\left(r^{2}=0,515, p<0,001\right)$ and chlorides $\left(r^{2}=0,993, p<0,001\right)$; as regards nutrients, only the nitrates were fairly related to suspended solids $\left(r^{2}=0,399, p<0,001\right)$ and total phosphorous $\left(r^{2}=0,366\right.$, $p<0,001) . \mathrm{pH}$ and dissolved oxygen showed significant correlation $\left(r^{2}=0,607, p<0,001\right)$, possibly as a result of the highest values reported at Stations E4, E5 and E6 in the 2006 sampling, where high cyanobacteria density was also reported.

The Principal Component Analysis (PCA) conducted for physical and chemical variables explained the $51,1 \%$ of the variability based on the first three components. The first variation trend is determined mainly by dissolved oxygen, $\mathrm{pH}$ and depth. The second component shows high correlation with conductivity and chlorides, while the third component, alkalinity, 
Table 1. Statistical summary of the physical and chemical variables included in the study (2006-2010). N: Number of samples; Stand. Dev.: Standard Deviation; C.V: Variation Coefficient. See description of the acronyms in the text.

\begin{tabular}{|c|c|c|c|c|c|c|}
\hline PARAMETER & $\mathrm{N}$ & Minimum & Maximum & Mead & Stand. Dev. & C.V. \\
\hline COND $\left(\mu S . \mathrm{cm}^{-1}\right)$ & 239 & 128,5 & 5640 & 258,45 & 427,79 & 1,66 \\
\hline $\mathrm{DUR}\left(\mathrm{mgCaCO} \cdot \mathrm{L}^{-1}\right)$ & 239 & 54,47 & 1076 & 89,52 & 78,94 & 0,88 \\
\hline $\operatorname{ALKA}\left(\mathrm{mg} \cdot \mathrm{L}^{-1}\right)$ & 239 & 25,7 & 121 & 63,66 & 11,69 & 0,18 \\
\hline $\mathrm{pH}$ & 239 & 4,47 & 9,17 & 7,27 & 0,50 & 0,07 \\
\hline TEMP $\left({ }^{\circ} \mathrm{C}\right)$ & 239 & 22,3 & 35,8 & 30,32 & 2,46 & 0,08 \\
\hline$T H C\left(m g \cdot L^{-1}\right)$ & 239 & 1,07 & 15,58 & 1,74 & 1,63 & 0,93 \\
\hline $\mathrm{NO}_{3}\left(\mathrm{mg} \cdot \mathrm{L}^{-1}\right)$ & 239 & 0,01 & 5,04 & 0,57 & 0,69 & 1,21 \\
\hline $\mathrm{NO}_{2}\left(\mathrm{mg} \cdot \mathrm{L}^{-1}\right)$ & 239 & 0,01 & 2,25 & 0,09 & 0,30 & 3,32 \\
\hline $\mathrm{NH}_{3}\left(\mathrm{mg} \cdot \mathrm{L}^{-1}\right)$ & 239 & 0,09 & 5,04 & 0,65 & 0,59 & 0,92 \\
\hline TKN $\left(\mathrm{mg} \cdot \mathrm{L}^{-1}\right)$ & 239 & 0,1 & 18,3 & 1,28 & 1,37 & 1,07 \\
\hline$T P\left(\mathrm{mg} \cdot \mathrm{L}^{-1}\right)$ & 239 & 0,01 & 0,49 & 0,11 & 0,09 & 0,76 \\
\hline$D O\left(m g \cdot L^{-1}\right)$ & 239 & 0,7 & 12,5 & 4,67 & 1,81 & 0,39 \\
\hline $\mathrm{Cl}\left(\mathrm{mg} \cdot \mathrm{L}^{-1}\right)$ & 239 & 0,5 & 1856 & 27,38 & 139,36 & 5,09 \\
\hline $\mathrm{SS}\left(\mathrm{mg} \cdot \mathrm{L}^{-1}\right)$ & 239 & 0,4 & 715 & 44,38 & 64,67 & 1,46 \\
\hline$B O D_{5}\left(\mathrm{mgO}_{2} \cdot \mathrm{L}^{-1}\right)$ & 239 & 1,81 & 7,87 & 2,27 & 0,85 & 0,37 \\
\hline $\mathrm{COD}\left(\mathrm{mgO}_{2} \cdot L^{-1}\right)$ & 239 & 7,08 & 80,2 & 22,43 & 9,80 & 0,44 \\
\hline Fcoli (UFC/100mL) & 239 & 0,00 & 21000 & 916,06 & 2674,04 & 2,92 \\
\hline DEPTH $(\mathrm{cm})$ & 239 & 16,00 & 725 & 215,64 & 178,24 & 0,82 \\
\hline TRANS $(\mathrm{cm})$ & 239 & 2,00 & 260 & 36,50 & 35,14 & 0,96 \\
\hline
\end{tabular}

is the variable that weighs the most (Figure 3a). In relation to the variables related to the operation, THC did not play a role in the variance of the first three components.

The space dimensioned by the first two components (Figure 3b) brings together the first samples taken in the years 2008 and 2009 mainly in Group I. These samples covered the two hydrological periods (low water and high water). In this group (circle), Stations E5 and E6 stood out, where the maximum historic values of $\mathrm{pH}$ and dissolved oxygen were reported. Group
II shows most of the samples taken in 2006 and 2007, which took place in high water and ascending waters.

In relation there to, variations in the physical-chemistry of the water from the wetland systems are mainly related to processes associated with the hydrological regime system, that is to say depth, which in turn causes changes in water chemistry ( $\mathrm{pH}$, oxygen), followed by variables associated with the industrial operation, such as chloride content, and the natural mineralization (conductivity) of the systems; and last but not least, variations in water alkalinity. 


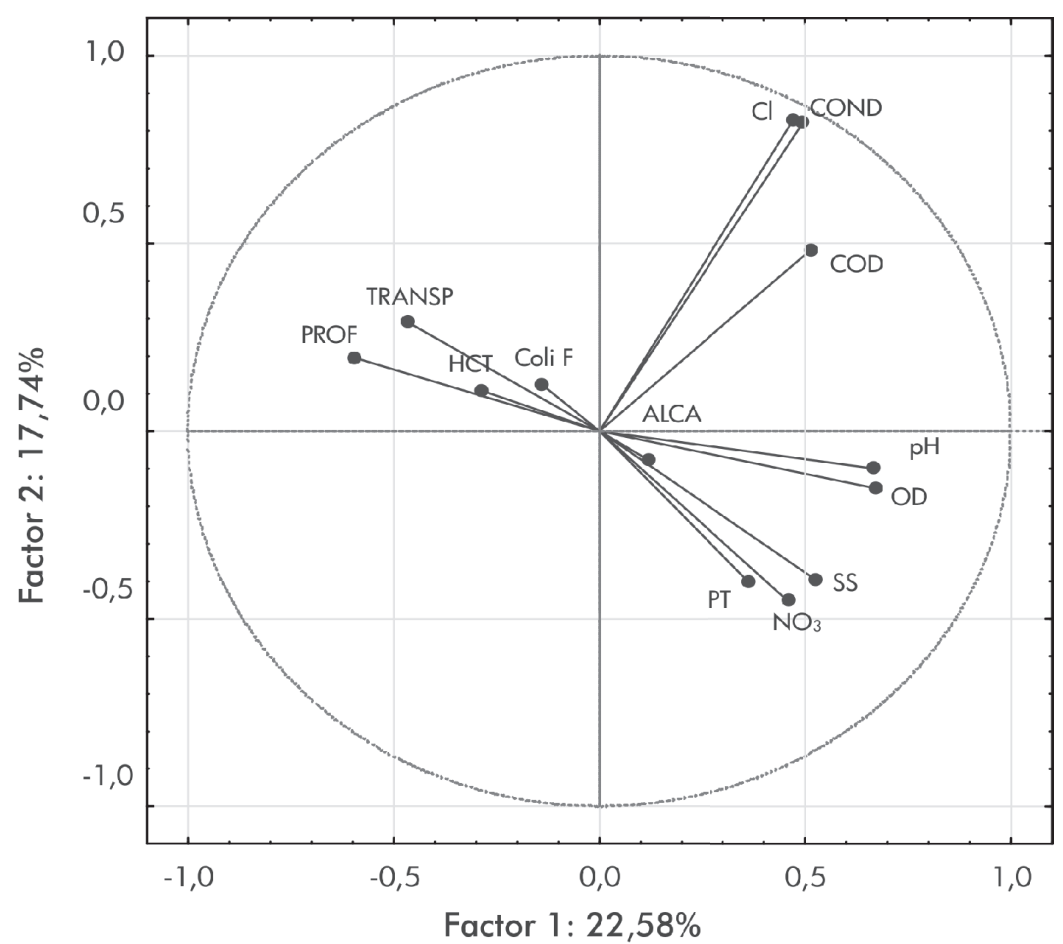

(a)

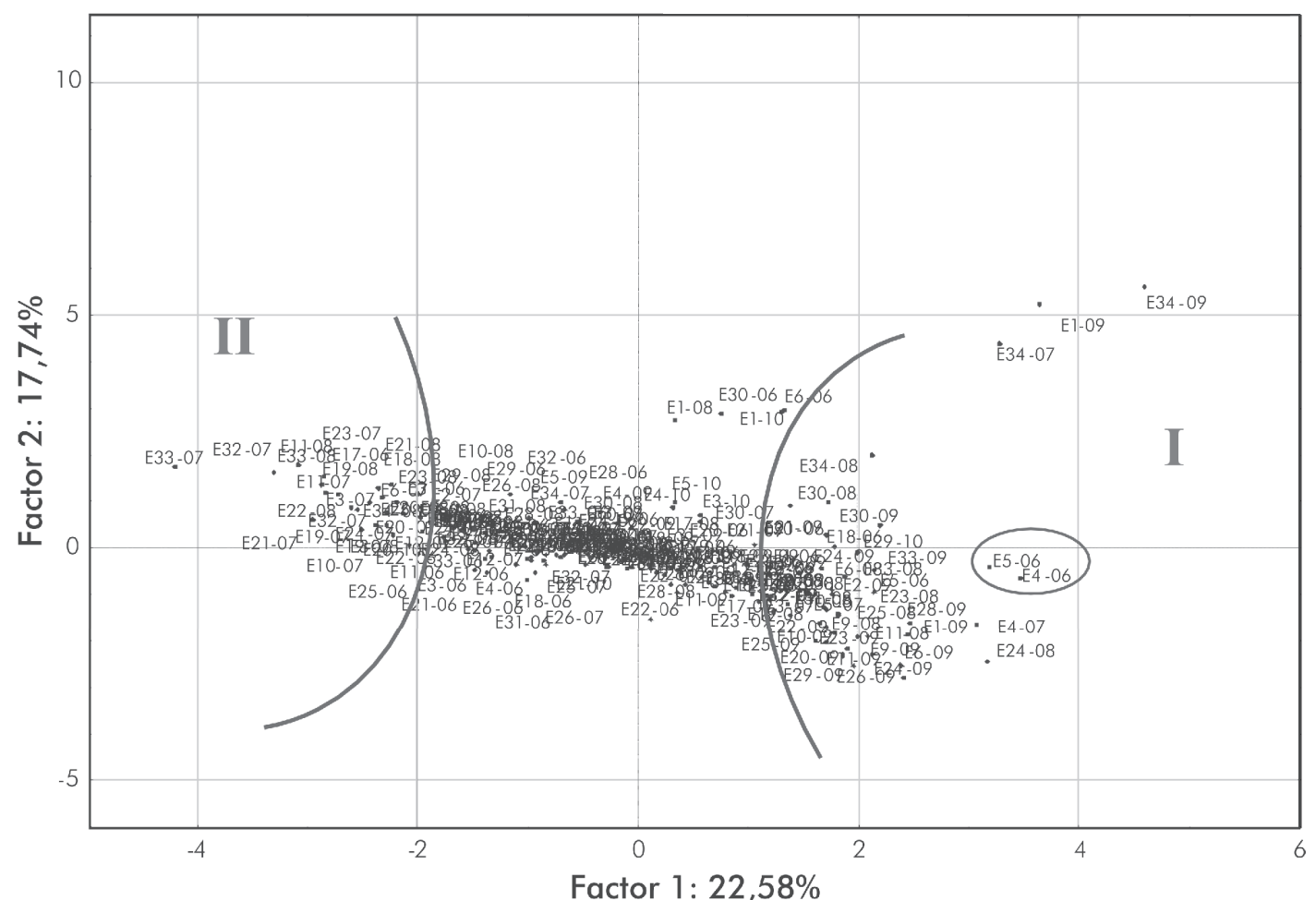

(b)

Figure 3. Principal Component Analysis (PCA) for the physical and chemical variables (a) of 27 swamps of the Momposina depression studied from 2006 to 2010. (b) Position of the samples in the space dimensioned by the first two components. The red circle shows the two stations with the highest $\mathrm{pH}$ values recorded. 


\section{Community Structure}

In general, Euglenophyceae was one of the groups that occurred the most throughout the study. Significant differences were found in its abundance as regards the three factors analyzed (point, year, sample), while Chlorophyceae and Xanthophyceae showed significant variations only in the year factor (Table 2).

Table 2. ANOVA for abundance at the class level for the factors conside-red in the study.

\begin{tabular}{|c|c|c|c|c|}
\hline $\begin{array}{l}\text { Taxonomic } \\
\text { Classes }\end{array}$ & & Point & Year & Sampling \\
\hline \multirow[t]{2}{*}{ Bacillariophyceae } & $\mathrm{F}$ & 1,791 & 5,129 & 6,683 \\
\hline & $P$ & 0,014 & 0,001 & 0,010 \\
\hline \multirow[t]{2}{*}{ Chlorophyceae } & $\mathrm{F}$ & 1,443 & 7,832 & 2,473 \\
\hline & $P$ & 0,084 & 0,000 & 0,117 \\
\hline \multirow[t]{2}{*}{ Dynophyceae } & $F$ & 0,991 & 2,941 & 5,249 \\
\hline & $P$ & 0,482 & 0,022 & 0,023 \\
\hline \multirow[t]{2}{*}{ Euglenophyceae } & $\mathrm{F}$ & 1,586 & 3,124 & 9,987 \\
\hline & $P$ & 0,042 & 0,016 & 0,002 \\
\hline \multirow[t]{2}{*}{ Xanthophyceae } & $\mathrm{F}$ & 1,094 & 3,687 & 0,395 \\
\hline & $P$ & 0,351 & 0,006 & 0,531 \\
\hline
\end{tabular}

The Euglenales was predominant specifically during the low water periods, with abundances of more than $90 \%$ at the E3, as well as E10, E11 and E23, where they had abundances greater than $70 \%$ at each station. In addition, the highest abundances of Oscillatoriales (Planktothrix, Pseudanabaena, Planktolyngbya, Oscillatoria) were reported during ascending waters periods, particularly at E1 and the three stations of $\mathrm{La}$ Borda Swamp (E4, E5, E6). The highest abundances of Chlorococcales were recorded at the same stations.

There is a very similar tendency in composition between samplings 1 and 2 in the years 2006 and 2007 (Figure 4), given the similarity of hydrological conditions. During said years, euglenoids, cyanobacteria and pennate diamtoms were the most abundant groups, in that order. As of the year 2008, changes related to temporality became more evident. The proliferation of pennate diatoms stood out in most of the ascending waters periods, particularly of Eunotia, Fragilaria, Synedra, Gyrosigma and Nitzschia.

Species diversity showed a high level of variation between the stations of the study (Figure 5). The highest average values were reported at E26, E32, E33, E29 and E3. The first is located in the southeastern zone and is the direct inlet for the Barranco Channel, while E32 is located to the northeast and is known by the inhabitants of the area of study as a good fishing sector. It has no wells, no effluents and cattle raising is the only activity around. Sites E4, E5, E6, E31 and E34 are known as the systems with the lowest average diversity and richness.

At the temporal level, the highest Shannon diversity values were reported during the ascending waters periods (1-2006, 1-2007) and high water periods (22006, 2-2007).

The highest dominance averages were recorded at E2. This point is located in the central sector of E1 Mechon Swamp, which showed the greatest hydrological variation, because it disappears completely during low water periods, leaving sectors E1 and E2 of the same swamp isolated and becoming a footpath and dirt road in the zone.

Although E31 is the reference site, it also showed a high dominance average, related mainly to the predominance of Nostocales, specifically Cylindros-permopsis raciborskii during several sampling periods, as well as Oscillatoriales (Planktothrix sp., Leptolyngbya sp.).

Given the similarity of the behavior of the indexes between the reference swamp and the swamps with the highest anthropic impact, said similarity was quantified based on a cluster analysis taking the average abundance of each of the Orders for each sampling. The results confirmed said assumption of similarity (Figure 6). 


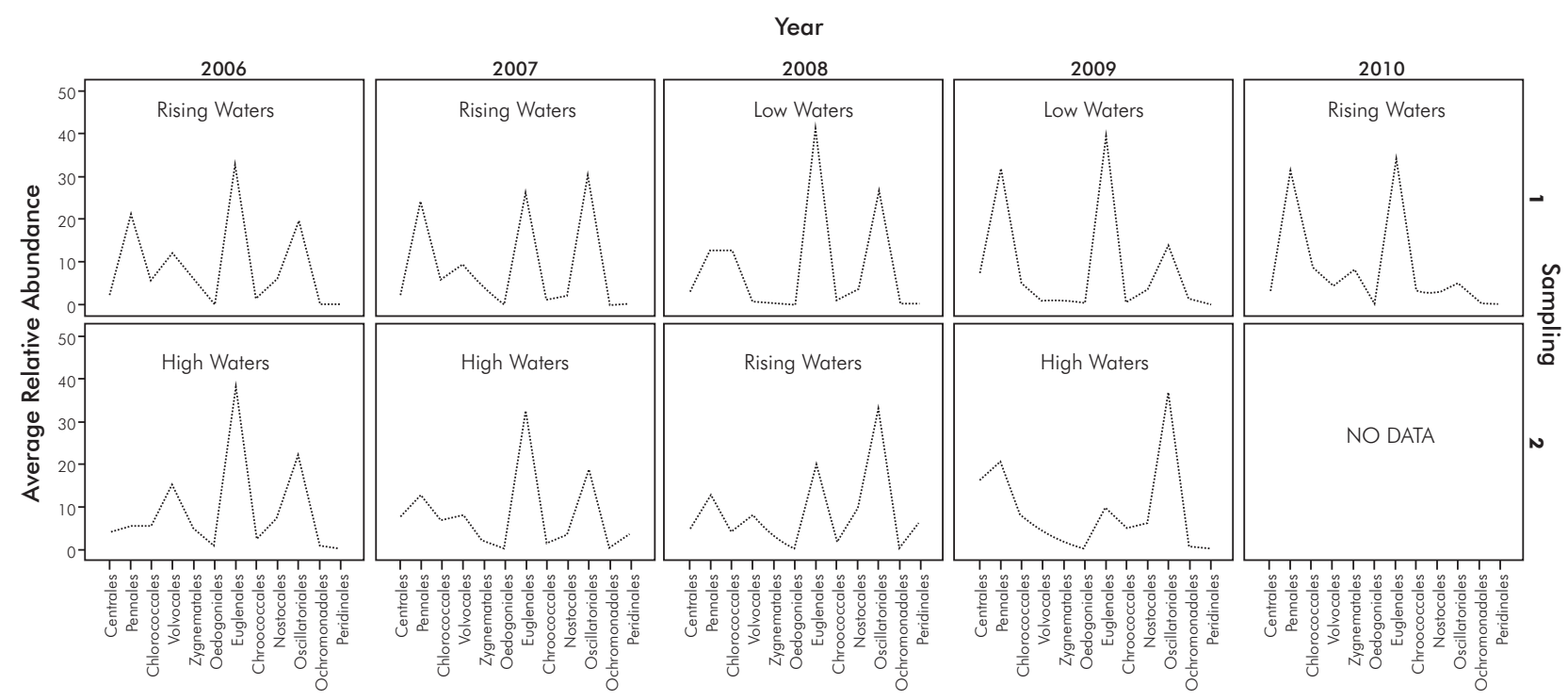

Figure 4. Fluctuations in average relative abundance at the order level in relation to hydrological periods in the zone of study (2006-2010).
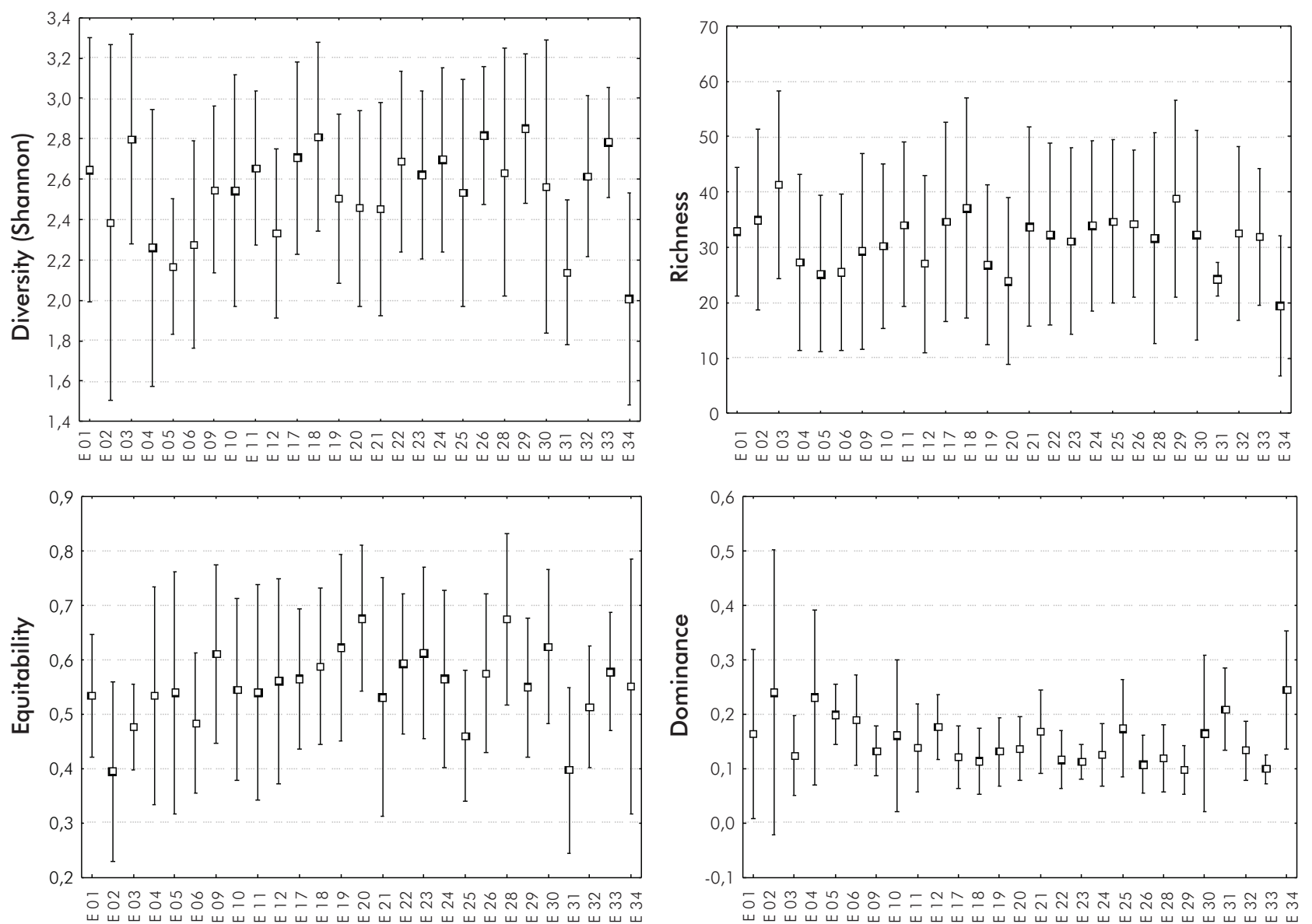

Figure 5. Ecological index for phytoplankton (2006-2010). () Average Shannon Diversity, Species Richness, Dominance and number of individuals. (I): Confidence interval for the mean at $95 \%$. 


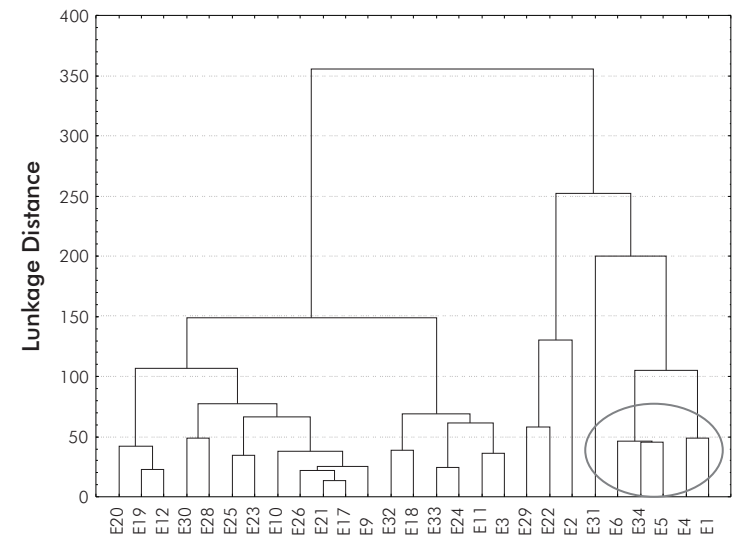

Figure 6. Cluster Analysis for the stations of study in the Momposina Depression. Similarity Measure Euclidian Distance and Ward's Amalgamation Algorithm. The cluster formed by stations with the most anthropic impact are show in circle with the reference swamp (E31).

\section{Relationship between Biological and Environmental Variables}

The tendencies of association of certain algal groups with the water's physico-chemical were analyzed based on a correlation analysis. During the rising waters period, the maximum correlation values were reported for Chlorococcales with conductivity, hardness and chlorides; followed by Oscillatoriales with $\mathrm{NO}_{3}$. The relationship between Nostocales and the availability of organic matter $\left(\mathrm{BOD}_{5}\right)$ and nitrites, as well as Oedogoniales and organic nitrogen, stood out for the high water period. During low water periods, Nostocales were highly associated with alkalinity.

The most significant variables in the PCA were the starting point to carry out the CCA. Environmental variables were included sequentially in the model using the forward selection procedure, and the Monte Carlo permutation test (2000 permutations) determined the statistical significance $(p<0,05)$ of each variable selected. Only 8 of the variables included were selected by said procedure. In all the runs, THC, depth, transparency and TP were not significant $(p>0,05)$. However, $C O D$ was included because it was at the decision limit $(p=0,06)$. In addition, the Orders whose occurrence was less than $10 \%$ of the total samples were excluded, thus discarding Chaetophorales, Cryptomonadales, Cladophorales, Gymnodiniales, Tetras-porales and Ulotrichales, which were considered rare or uncommon taxa in the plankton of the swamps studied.

Analysis showed that the relationship between species and environmental variables explained $83,5 \%$ of the variability in the first three axes and $9,3 \%$ of the variance of the species data. The variables that played the biggest role in the model in terms of the explained variance were $\mathrm{pH}(119,8 \%), S S(64,6 \%), C l(49 \%)$ and COND (53,8\%). Figure 7 illustrates the ordination of species and samples with environmental variables and Tables 4 and 5 show a summary of the model.

Table 3. Correlation values between relative abundance orders phytoplankton and the physical chemical variables during each of the hydrological periods studied. The values are Spearman's $r$ value at $p<0,05$ and $n$ is the total number of data in each analysis.

\begin{tabular}{|c|c|c|c|c|c|}
\hline \multicolumn{6}{|c|}{ Rising waters $(n=79)$} \\
\hline & $\mathrm{NO}_{3}$ & COND & HAR & $\mathrm{Cl}$ & $C O D$ \\
\hline Chlorococcales & - & 0,88 & 0,86 & 0,89 & 0,50 \\
\hline Oscillatoriales & \multicolumn{5}{|l|}{0,63} \\
\hline \multicolumn{6}{|c|}{ High Waters $(n=61)$} \\
\hline & $\mathrm{pH}$ & DO & $\mathrm{NO}_{2}$ & $\mathrm{BOD}_{5}$ & TKN \\
\hline Euglenales & $-0,58$ & $-0,52$ & - & - & - \\
\hline Oscillatoriales & 0,50 & - & 0,44 & - & - \\
\hline Nostocales & - & - & 0,70 & 0,62 & - \\
\hline Oedogoniales & - & - & - & - & 0,87 \\
\hline \multicolumn{6}{|c|}{ Low Waters $(n=52)$} \\
\hline \multicolumn{6}{|c|}{ ALCA } \\
\hline Nostocales & 0,55 & & & & \\
\hline
\end{tabular}

In general, there was no evident separation by sampling periods. Axis 1 shows a cluster of stations determined by ion content and organic load, as well as anthropic influence represented indirectly by $C O D$. Said stations (inside the circle) are the sites with the highest abundances of Oscillatoriales (Oscilla), Chlorococcales (Chloro), Nostocales (Nostoc) and Chroococcales (Chrooc), over different sampling periods at E31, E1, E2, E3, E4, E5, E6, E11. On the same axis toward the left quadrant there are site with low $\mathrm{NO}_{3}$ and $\mathrm{pH}$ concentrations represented by the Ochromonadales (Ochro), Volvocales (Volvoc) and Zygnematales (Zygne). There is a significant gradient on axis 2 given by the $S S$, separating one of the stations with the highest predominance of pennate diatoms (Penna).

The rest of the stations dispersed on axis 1 are related by the predominance of Euglenales (Eugle). 


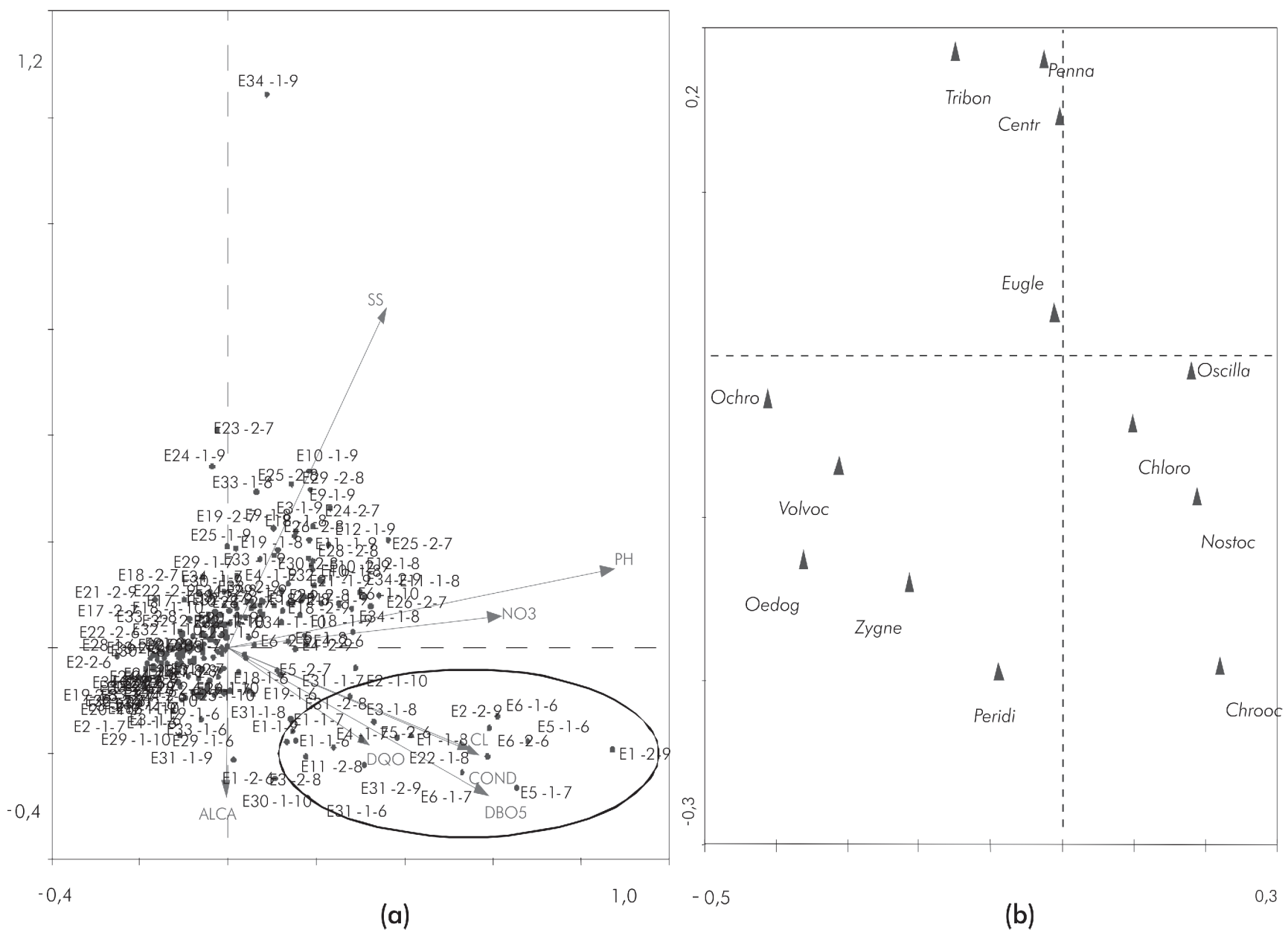

Figure 7. CCA of the phytoplankton, physical chemical and hydrological variables in the swamps studied (a) Biplot environmental variables and samples, (b) Species dispersion chart. See text for the acronyms of the orders.

Table 4. Canonical Correspondence Analysis - Model Summary.

\begin{tabular}{|c|c|c|c|}
\hline Axes & 1 & 2 & 3 \\
\hline Eigenvalues & 0,028 & 0,012 & 0,009 \\
\hline Correlation Species-Environmental Var. & 0,582 & 0,456 & 0,446 \\
\hline \multicolumn{4}{|l|}{ (\% Accumulated Variance) } \\
\hline Of the species data & 5,3 & 7,6 & 9,3 \\
\hline $\begin{array}{l}\text { Of the species-environmental Var. } \\
\text { relationship }\end{array}$ & 47,6 & 68,3 & 83,5 \\
\hline
\end{tabular}


Table 5. Summary of variable selection (forward selection). The order of the variables is based on the explained variance when they were included in the model.

\begin{tabular}{|cccccc|}
\hline Variable & $\begin{array}{c}\text { Variable } \\
\text { Code }\end{array}$ & $\begin{array}{c}\text { Lambda } \\
\mathbf{A}\end{array}$ & $\mathbf{p}$ & $\mathbf{F}$ & $\begin{array}{c}\text { Explained } \\
\text { Variance }\end{array}$ \\
$\mathrm{pH}$ & 4 & 0,02 & 0,001 & 7,19 & 119,83 \\
\hline $\mathrm{SS}$ & 14 & 0,01 & 0,002 & 3,88 & 64,67 \\
\hline $\mathrm{Cl}$ & 13 & 0 & 0,009 & 2,94 & 49,00 \\
\hline $\mathrm{COND}$ & 1 & 0,01 & 0,002 & 3,23 & 53,83 \\
\hline $\mathrm{NO}_{3}$ & 7 & 0,01 & 0,008 & 2,74 & 45,67 \\
\hline $\mathrm{ALKA}$ & 3 & 0 & 0,014 & 2,38 & 39,67 \\
\hline $\mathrm{BOD}_{5}$ & 15 & 0,01 & 0,015 & 2,38 & 39,67 \\
\hline $\mathrm{COD}$ & 16 & 0 & 0,060 & 1,77 & 29,50 \\
\hline
\end{tabular}

\section{ANALISYS OF RESULTS}

In the systems studied in the Momposina depression, there is an evident temporal change in ion and nutrient content that determine changes in alkalinity, conductivity, water hardness, and the inorganic forms of nitrogen and total phosphorous, which suggests that the temporal system caused by the hydrological phases covered in this study are important in water chemistry although significant temporal differences were not found in system depth.

In turn, the physical chemistry of the water at the spatial level is relatively consistent, except as regards the variables associated with the industrial operation (chlorides and $C O D$ ), which is related to Point E1, in which the highest organic load and salt content was detected throughout the study. The high values of chlorides and conductivity in E1 are associated with the effluents deposited in the swamp bed over several years of the field's operation by COLPET from the 1950s to the 1990s.

In general, conductivity values are greater than those reported in other systems of the Momposina depression (Montoya \& Aguirre, 2009b) and the Amazon systems (Pinilla, 2006). As regards $\mathrm{pH}$, the wetland systems in the area of influence have a neutral $\mathrm{pH}$ with several peaks of basicity during the ascending waters and low water periods, specifically in swamps with high cyanobacteria densities.

The nutrient dynamic showed contrasting behavior given that maximum $\mathrm{NO}_{3}, \mathrm{NO}_{2}$ and $\mathrm{TKN}$ values were reported during the ascending waters period, while there was a rise in TP during the low water period. This variable dynamic may suggest the high degree of complexity of the systems due to their connectivity. Most of the swamps do not drain in a preferential direction, they are highly dendritic and surrounded by a network of channels connected to one another, which bring in a significant amount of allochthonous material from the local basin. According to García-Lozano \& Dister (1990), the swamps in the Momposina depression occupy larger areas and hold greater volumes, making them less easily influenced by the contributions of the main river, while their tributary basins are more seasonal and their flooding periods are longer.

Although the algal composition was not very variable between one period and another, due to the similarity of the hydrological periods sampled, diatoms and euglenoids showed significant temporal differences between stations, samples and year studied. The permanent presence of euglenoidswas also reported in the flood lakes of the Parana River Basin (Zalocar De Domitrovic, 2003). Reynolds, Huszar, Kruk, Flores and Melo (2002) consider euglenoids within the W1 functional group, whose habitat consists of small systems with a large supply of organic matter, tolerant of high $B O D$ values. Our study confirmed this characteristic, given the relationship found between Euglenales with low $D O$ content and low $\mathrm{pH}$, which is typical of redox environments asso-ciated with decomposition of organic matter, possibly originated by the large quantity of aquatic vegetation (field observation).

The proliferation of pennate diatoms (Pennal) in most periods of rising waters may be related to the macrophyte belt drive to the limnetic zone of swamps, given that group has a benthic preference and the predominant forms found have mucilage pads or peduncles to adhere to vegetation.

Although Xanthophyceae and Dynophyceae presented lower abundance compared to other groups, 
could be considered as permanent components of phytoplankton of Momposina depression swamp complex, given the lack of variation among the factors "point" and "sampling". Its low abundance in the study may reflect the type of sampling carried out.

Although it is a well known fact that Chlorococcales are representative of the eutrophic plankton closely associated with shallow habitats rich in nutrients (Reynolds, 1997), there is no background of the close relationship between conductivity and chlorides and the abundance of this group.

The direct relationship between filamentous cyanobacteria (Oscillatoriales) and $\mathrm{NO}_{3}$, is related to the inlet of nutrients during the high water period. In addition, during said periods, there is a significant load of solids that limit the entry of light due to the increase in turbulence, thus allowing the development of genera such as Planktothrix and Pseudanabaena. This behavior might be extendible to other taxa such as Cylindrospermopsis, which has also been recorded particularly in the refe-rence swamp during low water as well as high water periods. Such taxa is typical of warm water with well mixed layers (Reynolds et al., 2002) and has the capacity to regulate floatability due to the presence of aerotopes, which keeps it in the surface layers of the water column, thus preventing losses by sedimentation.

Cylindrospermopsis raciborskii is considered a perennial specie of tropical and subtropical waters (Padisák, 2003) and has been widely cited in other countries as a toxin producer (for example, Azevedo et al., 2002; Lagos et al., 1999; Fastner et al., 2003). In Colombia, it has been recorded in the middle Magdalena basin (Plata-Díaz, Echenique \& Gavilán-Díaz, 2004) and the lower San Jorge Basin in the Momposina Depression (Hernández-Atilano, Aguirre, Palacio \& Ramírez-Restrepo, 2008) with significant densities in the phytoplankton.

In the Momposina depression, species diversity varies depending on the hydrological system. The highest values are recorded in periods of rise water levels, specifically in bodies of water that receive permanent effluents from channels of the local basin. On the other hand, swamps where flood-pulse flows have decreased due to the construction of roads (case of La Borda) present low diversity.

According to the $C C A$, species composition is not related to changes in the hydrological pulse. Although depth was a determining variable in the physicochemical variations of water, it was not determinant in the algal composition of the systems. However, the high content of salt, organic load, $\mathrm{NO}_{3}$ and base $\mathrm{pH}$ conditioned the proliferation of cyanobacteria and green algae (Chloroco-ccales) in a small group of swamps that included the reference swamp as well as those with high anthropic impact.

In turn, diatoms predominated in the swamps with high solids concentration. Pennate diatoms and euglenoids were especially common in all the bodies of water. Ochromonadales, Volvocales an Zygnematales were the taxa associated with low nutrient content and fairly acid $\mathrm{pH}$. It is a well known fact that desmidiales (Zygnematales) are typically recorded in oligo-mesotrophic lakes and their existence, even in low densities, is an indicator of fairly acid and oligotrophic conditions (Coesel, 1983).

Although all algal species have a range and an optimum for development, it is a well known fact that cyanobacteria dominate in very warm environments. Their occurrence is determined by their pigmentation and metabolic flexibility, among many other characteristics, which makes them tolerant to variable conditions such as nutrient concentration and low irradiance (DeNicola, 1996; Dokulil \& Teubner, 2000), thus their predominance in wetland systems not only with anthropic influence, but also in systems subject to drastic hydrological variations.

Although cyanobacteria dominance has been related to ecological health problems in reservoirs and natural lakes, given that said phenomenon is associated with eutrophication, several studies have shown that said condition constitutes a stable state of the algal community in turbid, shallow lakes (Scheffer, Rinaldi, Gragnani, Mur \& Van Nes, 1997). Therefore, the high cyanobacteria densities, particularly Oscillatoriales and Nostocales, recorded in the reference swamp as well as the swamps with greater impact (E1, E4, E5, E6) are not due to the level of anthropic alteration, but rather the typical dynamic of the wetland systems. The high 
cyanobacteria densities recorded in the phytoplankton of the Chucuri (Plata-Díaz, 2000) and Ayapel swamp complex (Hernández-Atilano et al., 2008. ) confirm that hypothesis.

Although total hydrocarbons are an important variable in monitoring contamination by oil operations, and it was preliminarily considered a possible influence on the algal community, was not part of the set of variables in the canonical model of this study. Although several wells are covered during high water periods, most of the systems have concentrations below screening level $(<1,4$ $\mathrm{mg} \cdot \mathrm{L})$, while the maximum concentrations recorded are no more than $15 \mathrm{mg} \cdot \mathrm{L}$, which may be due to local contamination by outboard motors. THC concentrations in sites highly contaminated by spills are in the order of $200 \mathrm{mg} \cdot \mathrm{L}$ - $300 \mathrm{mg} \cdot \mathrm{L}$ (unpublished data).

The study conducted by Viña et al. (1991) in the Zapatosa Swamp states that the damage to the phytoplankton community related to the oil spill was not substantial due to the low residence time of the water and the high reproduction rates of the algal community, which led to the rapid repopulation of the system.

In general, there is not much information regarding the effect of hydrocarbons on the phytoplankton structure of lentic systems, because there has been more interest in higher trophic levels and most of the data comes from experimental studies or mesocosms with marine microalgae (Huang et al., 2011; González et al., 2009; Vargo, Hutchins \& Almquist,1982). Although there is evidence that certain components of crude are toxic to microalgae causing damage at the biochemical level (Sikkema, Bont \& Poolman, 1995; Bopp \& Lettieri 2007), others indicate that there is no lethal effect in concentrations below 50 ppb (Gordon \& Prouse, 1973) and that high hydrocarbon concentrations $(\geq 2,28 \mathrm{mg} \cdot \mathrm{L})$ restrict the growth of marine phytoplankton and chlorophyll content, while concentrations below 1,22 $\mathrm{mg} \cdot \mathrm{L}$ stimulate the growth thereof (Huang et al., 2011). High proliferation of algae in contact with oil patches has been observed in lotic systems, although with a small number of tolerant species (López-Rodas et al., 2009). Both primary production (Carrera-Martínez, Mateos-Sanz, López-Rodas \& Costas, 2011) and chlorophyll (Banks, 2003) severely decrease right after spills as a result of the low penetration of light due to oil stains (González et al., 2009).

\section{CONCLUSIONS}

- Temporal variations in the physico-chemical of the water of the Momposina depression are related to changes in swamp depth. However, changes in phytoplankton community composition are not related to the hydrological periods studied. The proliferation of cyanobacteria and green algae in the systems both inside and outside the area of influence of the oil fields is determined by $\mathrm{pH}$, salt content, $\mathrm{NO}_{3}$, conductivity and organic load. In addition, the permanent presence of euglenoids is related to redox environments due to the decomposition of organic matter from aquatic vegetation.

- The variables indirectly related to the industrial operation $(\mathrm{Cl}$ and $\mathrm{COD})$ influence community structure, while $T H C$, an explicit variable of the oil operation, was not significant.

- The canonical model fits well in the search for the factors that determine the phytoplankton dynamic in the swamps studied. However, functional associations should be explored in order to find clearer patterns in the community structure, and more samples should be taken in the low water and ascending waters periods. In addition, the results obtained herein should be considered a first approach, because a longitudinal statistical model that includes other physical factors, such as river (flow) influence and water residence time in each of the systems, should be used to quantify the model that specifically summarizes the weight of the variables considered in this study.

\section{ACKNOWLEDGMENTS}

To the Biotechnology Lab team of Ecopetrol S.A. $I C P$, for their role in collecting the information, as well as the Water and Soil Lab team Ecopetrol S.A. - ICP, for their joint work on the field work and their commitment to all the analyses required.

To Professor Germán Moreno from the School of Mathematics of the Universidad Industrial de Santander for his role in the statistical analysis of the results of this study. 


\section{REFERENCES}

American Public Health Association (APHA). (2005). Standard methods for examination of water and wastewater. 21st edition. J. Amer. Pub. Heal. Asoc., Washington. 1536.

Azevedo, S. M. F. O., Carmichael, W. W, Jochimsen, E. M, Rinehart, K. L., Lau, S, Shaw, G. R. \& Eaglesham, G. K. (2002). Human intixication by microcystins during renal dialysis treatment in Caruaru-Brazil. J. Toxicology. 181-182: 441-446.

Banks, S., (2003). SeaWIFS satellite monitoring of oil spill impact on primary production in the Galapagos marine reserve. J. Mar. Pollut. Bull., 47 (7-8), 325-330.

Bopp, S. K. \& Lettieri, T. (2007). Gene regulation in the marine diatom Thalassiosira pseudonana upon exposure to polycyclic aromatic hydrocarbons (PAHs). Gene, 396 (2), 293-302.

Braak, C. J. F. ter \& Prentice, I. C. (1988). A theory of gradient analysis. Adv. Ecol. Res., 18: 271-313.

Braak, C. J. F. ter \& Smilauer, P. (1997). Canoco for windows Version 4.51. Biometrics-Plant research international. The Netherlands: Wageningen.

Carrera-Martínez, D., Mateos-Sanz, A., López-Rodas, V. \& Costas, E. (2011). Adaptation of microalgae to a gradient of continuous petroleum contamination. Aquatic Toxicology, 101 (2), 342-350.

Coesel, P. F. M. (1983). The significance of desmids as indicators of the trophic status of freshwaters. Schweizerische Zeitschrift für Hydrologie, 45 (29), 388-393.

Comas, A. (1996). Las Chlorococcales Dulceacuícolas de Cuba. Bibliotheca Phycologica. Berlín: J. Cramer.

Cox, E. (1996). Identification of freshwater diatoms from live material. New York: Chapman \& Hall.

DeNicola, D. M. (1996). Periphyton responses to temperatura at difference ecological levels. In: R. J. Stevenson, M. L. Botwell \& R. L. Lowe (Eds). Algal Ecology, Freshwater Benthic Ecosystems. San Diego: Academic Press.

Dokulil, M. \& Teubner, K. (2000). Cyanobacterial dominance in lakes. J. Hydrobiologia, 438 (1-3), 1-12.

Fastner, J., Heinze, R., Humpage, A. R., Mischke, U., EAGlesham, G. K. \& Chorus, I. (2003). Cylindrospermopsin oc- currence in two German lakes and preliminary assessment of toxicity and toxin production of Cylindrospermopsis raciborskii (Cyanobacteria) isolates. Toxicon, 42:313-321.

García-Lozano, L. C. \& Dister. E. (1990). La planicie de inundación del medio-bajo Magdalena: Restauración y conservación de hábitats. Interciencia, 15 (6), 396-409.

González, J., Figueiras, F. G., Aranguren-Gassis, M.,Crespo, B. G., Fernández, E. \& Morán, X. A. G. (2009). Effect of a simulated oil spill on natural assemblages of marine phytoplankton enclosed in microcosms. Estuarine, J. Coa. Shelf Scie., 83 (3), 265-276.

Gordon, D. C. \& Prouse, N. J. (1973). The effects of three oils on marine phytoplankton photosynthesis. Marine Biology, 22 (4), 329-333.

Hernández-Atilano, E., Aguirre, N. J., Palacio, J. A. \& Ramírez-Restrepo, J. J. (2008). Variación espaciotemporal de la Asociación Fitoplanctónica en diferentes momentos del pulso Hidrológico en la Ciénaga de Ayapel, Córdoba, Colombia. Actual Biol., 30 (88), 67-81.

Huang, Y. J., Jiang, Z. B., Zeng, J. N., Chen, Q. Z., Zhao, Y. Q., Liao, Y. B., Shou, L. \& Xu, X. Q. (2011). The chronic effects of oil pollution on marine phytoplankton in a subtropical bay, China. Environ Monit Assess, 176 (1-4), 517-530.

Instituto Colombiano del Petróleo (ICP) Ecopetrol. (2000). Diagnóstico ambiental del área de influencia de los campos Cicuco y Boquete. Fase I del plan de manejo ambiental. Informe Técnico. Bucaramanga. 150pp.

Instituto Colombiano del Petróleo (ICP) Ecopetrol. (2001a). Estudio de la Dinámica Hídrica. Área de Influencia Campos Cicuco Boquete. Informe Técnico. Bucaramanga. 3: $297 \mathrm{pp}$.

Instituto Colombiano del Petróleo (ICP) Ecopetrol. (2001b). Estudio de la dinámica hídrica y monitoreo de sedimentos de los humedales del área de influencia del campo Cicuco - Boquete. Caracterización Ambiental. Informe Técnico. Bucaramanga. 3: 297pp.

Instituto de Hidrología, Meteorología y Estudios Ambientales (IDEAM). (2010). Base de datos de valores medios mensuales de niveles Río Chicagua, Estación Guaymaral. Período 1991-2009.

Jongman, R. H. G., Braak, C. J. F. ter \& Van Tongeren O. F. R. (1995). Data Analysis in Community and Landscape Ecology. New York: Cambridge University Press. 
Junk, W. J., Bayley, P. B. \& Sparks, R. E. (1989). The flood pulse concept in river- floodplain systems. In D. P. Dodge. Proceedings of International Large River Symposium. J. Can. Spec. Public. Fish. Aquatic. Sci., 106: 110-127.

Junk, W. J. (1997). The central Amazon Floodplain. Ecology of a Pulsing System. Berlin: Springer-Verlag.

Komárek, J. \& Anagnostidis K. (1999). Sübwasserflora von Mitteleuropa Band 19/1. Cyanoprokaryota. 1. Teil: Chroococcales. Ettl H., Gärtner G., Heynig H. \& Mollenhauer (eds). Berlin: Elsevier.

Komárek J. \& Anagnostidis K. (2005). Süsswasserflora von Mitteleuropa 19/2. Cyanoprokaryota 2. Teil/ 2nd Part: Oscillatoriales. In: Büdel B., Krienitz L., Gärtner G. \& Schagerl M. (eds). Heidelberg: Elsevier.

Krammer, K. \& Lange-Bertalot, H. (1991a). Süsswasserflora von Mitteleuropa, Band 2/3. Bacillariophyceae. 3. Teil: Centrales, Fragilariaceae, Eunotiaceae. On Ettl, H., Gerloff, J., Heynig, H. \& Mollenhauer, D. (eds). Stuttgart: Gustav Fischer Verlag.

Krammer, K. \& Lange-Bertalot, H. (1991b). Süsswasserflora von Mitteleuropa, Band 2/4. Bacillariophyceae. 4. Teil: Achnanthaceae, Kritische Ergänzungen zu Navicula (Lineolatae) und Gomphonema, Gesamtliter-aturverzeichnis Teil 1-4. On Ettl, H., Gärtner, G., Gerloff, J., Heynig, H. \& Mollenhauer, D. (eds). Stuttgart: Gustav Fischer Verlag.

Lagos, N., Onodera, H, Zagatto, P. A, Andrinolo, D, Azevedo S. M. F. Q. \& Oshima, Y. (1999). The first evidence of paralytic shellfish toxins in the freshwater cyanobacterium Cylindrospermopsis raciborskii, isolated from Brazil. Toxicon, 37 (10), 1359-1373.

López-Rodas, V., Carrera-Martínez, D., Salgado, E., MateosSanz, A., Báez, J. C. \& Costas, E., (2009). A fascinating example of microalgal adaptation to extreme crude oil contamination in a natural spill in Arroyo Minero, Río Negro, Argentina. J. An. R. Acad. Nac. Farm., 75 (4), 883-899.

Montoya, Y. \& Aguirre, N. A. (2009a). Estado del arte de la limnología de lagos de planos inundables. Gestión y Ambiente, 12 (3), 85-106.

Montoya, Y. \& Aguirre, N. A. (2009b). Cambios nictemerales de variables físicas y químicas en la Ciénaga de Paticos, complejo cenagoso de Ayapel, Colombia. Rev. Biol. Trop., 57 (3), 635-646.

Padisák, J. (2003). Estimation of minimum sedimentary inoculum (akinete) pool of Cylindrospermopsis raciborskii: a morphology and life-cycle based method. Hydrobiologia, 502: 389-394.

Palmer, M. W. (1993). Putting things in ever better order: The advantages of canonical correspondence analysis. Ecology, 74 (8), 2215-2230.

Palmer, M. W. (2010). Ordination methods for ecologist. Botany Department, Oklahoma State University [On line]. [Accessed: $1^{\circ}$ October, 2010]. Available at: http:// ordination.okstate.edu/index.html

Pinilla, G. A. (2006). Vertical distribution of phytoplankton in a clear water lake of Colombian Amazon (Lake Boa, Middle Caquetá). Hydrobiologia, 568 (1), 79-90.

Plata-Díaz, Y. (2000). Distribución horizontal, biomasa y productividad primaria de la comunidad fitoplanctónica de la Ciénaga de Chucurí. Tesis de pregrado. Facultad de Ciencias, Universidad Industrial de Santander, Bucaramanga, Colombia, 126pp.

Plata-Díaz, Y., Echenique, R. \& Gavilán-Díaz, R. A. (2004). Primer registro de Cylindrospermopsis raciborskii (Wolosz.) Seenaya \& Subba Raju en un lago de llanura aluvial en aguas dulces de Colombia. VI Seminario Colombiano de Limnología. Montería. 97.

Ramírez, A. \& Viña, G. (1998). Limnología Colombiana. Aportes a su conocimiento y estadísticas de análisis. BP Exploration Company (Colombia) LTD. Bogotá: Fundación Universidad de Bogotá Jorge Tadeo Lozano.

Reynolds, C. S. (1997). Vegetation processes in the pelagic: a model for ecosystem theory. Excellence in Ecology, 9. Germany: Ecology Institute.

Reynolds, C. S., Huszar, V., Kruk, C., Flores, N. \& Melo, S. (2002). Toward a functional classification of freshwater phytoplanckton. J. Plankton Research, 24: 417-428.

Roldán, G. \& Ramírez, J. J. (2008). Fundamentos de Limnología Nerotropical. 2da. Edición. Medellín: Universidad de Antioquia.

Scheffer, M., Rinaldi, S., Gragnani, A., Mur, L. R. \& Van Nes, E. H. (1997). On the dominance of filamentous cyanobacteria in shallow, turbid lakes. Ecology, 78 (1), 272-282.

Sikkema, J., Bont, J. A. M. \& Poolman, B. (1995). Mechanisms of membrane toxicity of hydrocarbons. Microbiology Reviews, 59 (2), 201-222. 
Statsoft, Inc. (2007). Statistica (data analysis software system), version 8.0. www.statsoft.com.

Tell, G. \& Conforti, V. (1986). Euglenophyta pigmentados de la Argentina. Bibliotheca phycologica, Bd. 75. Berlín: J. Cramer.

Vargo, G. A., Hutchins, M. \& Almquist, G. (1982). The effect of low, chronic levels of No. 2 fuel oil on natural phytoplankton assemblages in microcosms: 1. Species composition and seasonal succession. Marine Environmental Research, $6(4), 245-264$.

Viña, G., Ramírez, A., Lamprea, L., Garzón, B., SchmidtMumm, U., Rondón, E. \& Flórez, C. (1991). Ecología de la Ciénaga de la Zapatosa y su relación con un derrame de petróleo. Informe Técnico. Ecopetrol-DCC, Cúcuta. $114 \mathrm{pp}$.

Wehr, J.D., Sheath, R. G. \& Thorp, J. H. (2002). Freshwater Algae of North America: Ecology and classification. California: Academic Press.

Zalocar De Domitrovic, Y. (2003). Effect of fluctuations in water level on phytoplankton development in three lakes of the Paraná river floodplain (Argentina). Hydrobiologia, 510: 175-193. 